\title{
GERÇEK VE HAYAL YÖNLERİ ILE OTOMASYON
}

\section{Ceviren : İbrahim YASA}

«Daedalus'un şaheserlerinin kendiliklerinden hareket etmesi, Vulcan'ın sehpalarının kutsal görevlerini kendi kendilerine yapmaları gibi farzedin ki, her âlet emir almadan, kəndi kendine işini yapabilir. Yine farzedin ki, tezgâhların mekikleri kendiliklerinden kumaş dokuyor. Bu durumdaki imalâthanede müdürün yardımcılara, Efendilerin esirlere artık ihtiyacı kalmayacaktır.» Aristo

Geçen son yillar içinde, çok gelişmiş memleketlerde insanca içleri âdeta bomboss, fakat tam faal halde fabrikalar gördük. Böyle bir manzara, modern bir efsane, otomasyon efsanesinin, yaratılması için gerekli olan bütün elemanları ortaya koymuştur. Geleceğe ait boş inançların her zaman, yenileşmeyi cürüm sayan gelenekçiliğinin direnmesiyle karşılaşması yüzünden, bu yeni doğan durumun karşısında hemen şiddetli tenkitler belirmiştir. Bu tenkitler, otomasyon, otomatik, otomatize olma gibi kelimeler konuşulduğu zamanlar görülmektedir. Bu tenkitleri gözden geçirmek için biraz mesele üzerinde durmak gerekir. Çünkü, kelimenin dış kabuğu içine o kadar muhtevası yakındır ki, birine dokunmadan öbürünïi kavramak mümkün değildir.

Otomasyon terimi 1936 yılında Birleşik Amerika'da doğmuş: O zamanlar General Motor Şirketiyle çalışan D. S. Harder tarafından ortaya atılmıştır. Bu kelime, insanoğlunun, birbirinden farklı, fakat birbiriyle yakından ilgili iki olayın farkına varılması ile başlamışır. Bu olaylar şunlardir :

1) İnsan emeğinin yerini makinenin alması akımının hızlandırılıp genişletilmesi,

2) Bu gelişsmeyle ilgili olarak alışı olduğumuz metodlardan çok daha esnek metodların ortaya çıkmasıdır. 
İk olaya otomatize olmak, ikincisine otomasyon demek doğru olur. Otomatize olmakla, elâstikî otomatize olmanın, yâni, otomasyonun arasında, bir çalar saatle termostat arasındaki kadar geniş ayrını vardır. Aynı karşılaştırma öğretim alanında da yapılabilir. Örneğin, bir anfiteheatre dolusu ögrenciye yetkiyə dayanılarak verilen ders veya radyo ile ögretim yaparak bir hocanın ögrencilerinin tepkilerini anlamaya çalışması arasındaki fark gibi...

Eğer okuyucu bu ayırımı, bu makalenin maksadı uğruna kabul ederse, otomasyonu, otomatize olmanın özel bir şekli olarak inceleyebiliriz (*).

Bu ayırım, otomatize olmanın, sert ve elâstikî şekilleri arasında birçok ortaklaşa noktalar bulunduğu gerçeğini gizlemek maksadıyla yapilmamıştır. İkisi de insan emeğinin kesin bir tahlilinin mümkün olmasını şart koşmaktadır. Bu tahlili temel alarak, ikisi de uygun programlar hazırlayabilmeli ve bu programları makinelere uygulandırabilmelidirler. Yâni belirli aralıklarla bu makinelerin çalışmaya başlamasına, çalışmasının hızlanmasına, yavaşlamasına ve durmasına emredebilmelidirler. Böylece çalısmaları ve doğurdukları sonuçları kontrol edebilmelidir.

Otomatize oluşun kaynakları, tarihin derinliğinde kaybolmuștur. Ilk otomatik makineler Misırlılara aittir. Eski ve Orta Çağda, Rönesans'da, Uzak, Yakın Doğuda ve Batıda insanlar eğlence maksadıyla, insan, hay-

van veya bilinen eşyalardan yararlanarak oldukça karışı işler yapabilen küçük makineler yapmışlardır. Fakat 18. Yüzyılda, mekaniğin ilerlemesiyle bu gibi garip merak ve eğlencenin tekelinden çıkıp fabrika mamullerine uygulaıma çığıı açılmıştır. Bu geçişi Joseph Tacquard'ın otomatik tezgâha geçişi temsil etmektedir.

Aristo'nun bir düğmeye basmakla işleyen fabrikası artık hayal olmaktan çıkmıstır. Çünkü, insanlar böyle fabrikaları meydana getirmek için uğraşıyorlardır.

(*) Avrupa, Amerika ve Sovyetler Birliğinde bir çok yazarların, bu ayırımda bizimle aynı fikirde olmadı̆̆ına dokunmak isterim. Onlar otomasyon kelimesini bizim otomatize olmağa verdiğimiz anlamda kullanarak, sert ve yumuşak șekilleri arasında bir ayırım yapmakta, ben de bu yüzden onları tenkit etmekteyim. 
Fakat bu ilk başarılar, mekaniğin iki engelinden yavaşlık ve temastan zarar görüyorlardı. Elektroniğin müjdecisi olan, elektriğin keşfi bu iki engeli de yenmeyi mümkün kılmıştır. 19. Yüzyılda biraz mütereddit olarak, 20. Yüzyılda ise daha büyük güven ve maharetle, endüstri alanında büyüik ölçüde tam mekanikleşməye girişildi. Herbiri bir tek makine tarafundan kontrol edilen 14 makineli Corning Cam Sirketi saniyede 30 ampul imal etmek suretiyle, Amerika'da kullanilan elektrik ampullerinin $\% 90$ inı imal edebildi. Sovyet Stankonstructia Fabrikası, insan eli değmeden eritilmiş madenden silâh imal etme imkânına kavuştu.

Muhafazakâr otomatizeye karşı, otomasyona verebileceğimiz belli başIt görevler nelerdir?

Ilkönce, makinenin çalışmasını kontrol edecek, onunla ilgili bir organ veya bir başka makineye ihtiyaç vardır. Çünkü, makinenin çalışması esnasında sürat, basınç, hararet, istihsal aksaklıklarını düzeltmek, bazı hallerde hataları tamir etmek, bozukluk ve kazaları haber vermek gerekir. $\mathrm{Bu}$ alanda da Thomas Watt'n icat ettiği buhar guvernorundan, endüstriel ve her gün kuilanilan termostatlara kadar, otomasyonun tarih öncesi, orijinalliğini ancak son zamanlarda farkedebildiğimiz, çok iyi bilinen örneklerdir. Bugün kendi kendini düzenleyen makineler hususunda başarilan işler, bahsettiğimiz eski olumlu başarılardan çok daha ileridir. Bugün otomatik ikameyi hem yağlamak suretiyle koruyucu, hem de bizzat tâmirler yapmak suretiyle verici âlet yapmak imkânı hasıl olmuştur. Örneğin, Sundstrand Makine Alet Şirketi tarafından imal edilen bir torna tezgâhı belirli bir aşınmadan sonra âleti otomatik olarak değiştirmektedir.

İkinci olarak otomasyon malın kalitesinin kontrolu yanında, her tek operasyonun kontroll imkânını vermektedir.

$\mathrm{Bu}$ durum bir taraftan imalâtın her safhasında çıkan işin uygunluğı ile, makineden beklenenin değerlendirilmesini mümkün kılmaktadır. Öbür taraftan, tamamlanan malı tahlil ederek bozucu elemanları etkisiz hale getirmektedir.

Muhafazakâr otomatize oluşun çeşitli yönleriyle kendi kendini kontrol ve kendi kendini tanzim'in eletronik veya foto-elektronik cihazlarla ifa edilen çifte ameliyesini birleştirerek kimya endüstrisinde sıvıların tahliliyle ilgili büyük başarılar elde edilmiştir. Bu sonuç yukarda sözï geçen 
endüstri çeşitlerinin devamlı imalât ameliyesi esasına dayanmasından ileri gılmektedir. Bunlar, otomobil imalâtında olduğu gibi değişik ameliyelerin birleşimi olan durumlardan daha kolay idare edilebilirler. Eugene Ayres tam otomatik bir petrol tasfiyehanesini şöyle tasvir etmektedir: Buranın mürettebatı, görevi yalnız kontrol levhasına nezaret etmek olan iki kişiden ibarettir. ìki kişi olmasının sebebi de, birinin hastalanması, uyuyakalması veya âniden ölmesi tehlikesidir.

Nihayet kesin otomatize oluşla otomasyonun iyi plânlamış bir birleşimi, gittikçe daha geniş endüstri alanlarında, ayn şubelerdeki birçok makinelerin işbirliğini geliştirmeyi mümkün kılmıştır. Öncü alaylarda önemli rol oynayan büyük elektronik hesap makineleri bir programin dengesini sağlamakla görevlidir. Bu program devamlı olarak gözd nn geçirilerek her safhada meydana gelen ilerleme ve gerilemeler kaydedilebilir.

Transfer makineleri muhakkak kt, otomasyonun zirvesini teskil eder. Bu makineler; imâl etme, ögitme, delme, düzeltme, elemə, makinenin çalişısını kontrol etme, tamamlanan işin kalitesini muayene etme, işi bir makineden diğerine nakletme, tamamlanan işin taşinmasinı sağlama gibi işleri yapmaktadırlar.

Tabiî otomatik paketleme sistemi, otomasyondan önce var olan bir transfer ameliyesinin örnağidir. Fakat bu ameliye yalnız sişe ve konserve kutusu gibi băsit şekilli ve makineden çıkarken hep aynı durumda olan eşyalarla ilgili idi. Halbuki, bugünün transfer makineleri sade zincirleme bir ameliye olmakla kalmayıp, nakliyatta rastlanan önceki zorlukları gözönünde tutarak işleri gerekli yöne yöneltebilecek elâstikiyete sahiptir.

$1923^{\prime}$ te Morris Motor Sirketi bir transfer makinesine yatırım yapts. Fakat imalâttaki artış maliyet fiatını karşılamadı. Ancak 20 yıl sonra Dẹtroit'deki FORD Motor Şirketinde ekonomik bir transfer makinesi başarı kazanmiş bülunuyordu. Fransa'da II inci Cihan .. Savaşı ve işgal zamanı transfer makinelerini inceleyen; sonra da bunları otomobil, traktör gibi çeşitli imalât alanlarına yayan ve geliştiren Renault Motor Sirketidir. Bu sayede Sovyetler Birliği «Rotor Lines» adı altında geliştirdiği bir usul için büyük reklâm yapmaktadır. "Rotor Line» bir seri rotordan (*) meydana gelir. Bunun özelliği, esyalar hareket halindeyken makineler tarafından

(*) Rotox = generatörün, dönerek voltaj sağlayan kismi. 
imâl edilmesindedir. Makinenin âleti, yapılan işle beraber ilerler. Çeşitli işlerin-süresi belli olmadığından eşit olmayan değişik âletlerle mücehhez rotorlar kullanmak gerekmektedir.

Imalâtın otomasyonla fethi henüz ilk safhasındadır vé birbirine eşit olmayan gelişmelerle karakterize edilmiştir. Mekanik endüstride de derin etkiler yapmasına rağmen en büyük başarılar kimya ve elektrik sahalarında clde edilmiştir. Nihayet, eğer otomatize oluşu tam randımanla, her şekli vz bütün kaynaklanyla kullanmağa mecbur olan bir alan varsa bu muhakkak Astronomi alanıdır. Diğer taraftan tarım ve bir dereceye kadar madencilik bu Ikinci Sanayi Devrimi ile mümkün olabilecektir. Otomasyon sadece işçiye tesir etmekle kalmamakta, otomatize olmanın kesin ve elâstikî şekilleri ofislerde, idarî işlerde, fırıncılıkta ve ekonomik plânlamada kendini his ettirmektedir.

Hattâ ögretim bile bunun etkisi altında kalmıştır. Tabiî otomasyon, ögreticinin, yeri doldurulamayan görevini üstüne alma hevesinde değildir. Fakat otomasyon ögretmene pek lâzım olan yardımı sağlıyacaktır. Makineler, ̈̈ğrencilere soru ve problemler takdim edecek, alınan cevaplara bakarak dersin kavranmıs olup olmamasina göre başka uygun sorular araştıracaktır.

Bazı kesin programlar, mümkün m:rtebe zorlukların önüne geçeğgi hedef almışlardır. Makinenin «sıhhatinin yerinde olmasını» şart koşmaktadırlar. Diğer taraftan elâstikî programlar «hastalığa», yani, kazalara, felâketlere karşı kimseler için çareler aramaktadır. Bu çarelere, 1868'de elektrodinatik tecrisinin kurucusu olan Maxwell tarafından başlanmış olan W/att'in guvernoru iyi bir örnektir.

Tabiidir ki, buhar makinesinin şaftının dönme sürati, kazandaki yanmanın şiddetine bağlidır. Bu yanma, birden bire yavaşlama veya hızlanma gibi sürat değişiliklerine sebep olan gayri muntazam bir olaydır ve buhar kabının açılışını muntazamlaştırmakla düzeltilebilir. Watt'dan önce bu kontrol için bir teknisyene ihtiyaç vardı. Hem nezaret etme masrafını ortadan kaldıran, hem de işi bir şahsın kararına terkedilmekten kurtaran otomatik guvernor şafta geçirilmiş dikey bir dingilden meydana gelmektedir. Bu dingilin tepesinde, kıvrık iki kol ve kolların her birinin dışa bakan ucunda ağır birer top bulunmaktadır. Normal süratte bu top denge halindedir. Şaft çok hızlı (veya çok yavaş) dönmeye başlayınca guvernor da daha hızh (ve- 
ya daha yavaş) döner. Merkezden uzaklaşmaya çalışan (centrifugal) kuvvetler yükselir (veya hafifler). Bu da madenî topları yükseltir (veya alçaltır). Böylece bu topların kaldıraç sistemiyle birbirlerinden uzaklaşmaları (veya birbirlerine yaklaşmaları) buhar kabındaki miktarın tam istenilen oranda azalması (veya çoğalması) ile sonuçlanır. Bu suretle insan eli değmeden, bütün makine normal süratine getirilmiş olur.

Hizmetkâr-mekanik ile canlı varlıklar arasındaki mukayese boşuna yapılmamıştır. Çünkü, bazı ameliyelerde kendi hatalarını düzeltme işlemi o kadar canlı olarak görülmektedir $\mathrm{ki}$, esasen hayat yanlışlıkların onarımı sistemine dayaniyor diyebiliriz.

Zaten, yanlışlıkların onarımı fikri epey eskidir. Asıl yeni olan, onun kuvvetini ve çeşitini, kullanılış şekillerini yeni farketmiş olmamızdır. Bunun uygulanması Naslin'in ifade ettiği gibi, teknolojinin, insan gayretinin, dikkatinin, hâfızasının ve karar verme kabiliyetinin yerini almasıdır. Bu açıdan bakılırsa otomasyon bilgi teorisi üzerine inşa edilmiş olan cybernetiklc ilgilidir (*). Bu yüzden, otomasyonun doğumunun, cybernetik'in doğumundan birkaç sene sonra meydana gelmesi bir tesadüf eseri değildir. Yine bu çok önemli ve büyük gelecek vaadzden iki yeni gelişmenin neden devamlı olarak küçük görüldüğünü, şarlatanlığa ve anlamsız gevezeliğe maruz kaldığını açıklamaya yardım eder. Modern fantazilere karşı, açık, objektif ve iyı düşünülmüş açıklama usulleri ve savunma yolları araştırmak zorunluğu vardır.

Konumuzun gerektirdiği, önemli sonucu çıkarmadan önce otomatize oluşun ister katı, ister elâstikî şekli olsun, Sovyetler, Amerika ve Batı Avrupa arasındaki ekonomik rekabette oynayacağı kesin role işaret etmek yerinde olur. Güin̈umüzün rekabetinin daha üstünde, insanoğlunun yerini makinenin alması, insanların kendi aralarında ve tabiatla olan münasebetlerinde radikal bir takım değişiklikler meydana getireceğine şüphe olmamalidır.

(*) Otomasyonda olduğu gibi eybernetik’in tarifinde de yazarlar arasında göriiș birliği yoktur, bu yüzden de anlaşamamazlıklar doğmaktadır. Ben, hị olmazsa otomasyonun anlaşılmasına yardım edecek olan aşağıdaki tarifi teklif ediyorum: Cybernetik uyabilme ilmi, onun tabî̉ başarıları, soyut teorisi ve pratik kullamılısıdır. 
Insan mukadderatına etkisini esas alarak, teknik ilerlemeleri üç grupta inceleyebiliriz :

1) Yeni ve arzu edilen eşya ve hizmetlerin keşfi,

2) Bilinen malların daha kısa zamanda imâline elverişli usullerin bulunmasi,

3). Bilinen malların daha az enerji sarf ve daha az kaza tehlikesile imâlini mümkün kılacak usullerin icadı.

Birinci şıkda ilerleme daha uzun zaman, daha çok çalışmakla mümkündür. Fazla emek pahasına yeni keşfi isteyip istememek toplumun karar1na kalmıştır. İkinci şıkta görev azalmıştır. Üçüncü şıkta ise sade bazı faydalar söz konusudur. Bu yüzden toplumsal problem ortaya çımaz.

Otomasyonun ikinci ve üçüncü gruba dahil olduğu açıktır. Otomasyonun herhangi bir alana girmesiyle müstahdem toplamında (Teknisyen, işçi v.s.) bir indirim olur. Yeni otomatik makinenin inşası için lâzım olan müstahdem de gözönüne alınsa bile sonuç pek değişmez. Otomasyonưn muhakkak işsizliğe sebep olacağını farzetmek doğru değildir. Eğer gerçek böyle olsaydı ne otomatize oluş, ne de Fennî Çalışma Organizasyonu ilerlemeyi tercih ederdi. İkinci sıkka ait icatlardan bugüne kadar işsizliğe yol açmamasi için hiçbir ilerleme yoktur. Fakat bu sonucu değiştirip, bazı kimselerin işsiz kalması yerine, ücretlerde indirme yapılmaksızın bütünün çalışma saatlerini azaltmak, toplumun elindedir. Bu sade sosyal adâlet meselesi değil, ekonomide çok önemli olan denge meselesi ile de ilgilidir. Walter Reuter «Makineler sadık köleler gibi olup, hiçbir zaman grev yapmıyabilirler ama fena müşteri oldukları muhakkaktır; çünkü yaptıkları malları satın aldıklatı görülmemiştir» demektedir.

$\mathrm{Bu}$ ihtiyaçların icabettiği gibi adilâne halledildiğini farzedelim. $\mathrm{O}$ zaman ortaya başka bir problem çıkacaktır: Bu şekilde tasarruf edilen is saatlerini yapıcı dinlenme ve faydalı faaliyetlere çevirmek; bu ehemmiyetsiz bir iş değildir. Çünkü, burada insanoğlunun tabiatı söz konusudur. Bahse konan meblâğ yüksek, mükâfatlar fevkalâdedir ama başka tercih hakkımız. var $\mathrm{mi}$ ?

Tedavinin bir dereceye kadar hastalıktan doğması da mümkündür. Otomatize oluş yalnız insan emeğini azaltmakla kalmayacak emeğin şeklini 
değiştir ıcektir. Bazı teknik özelliklerin ortadan kalkıp, yerlerini yenilerinin alması sonucunda iş tasnifinin baştan yapılması gerekecektir. Otomasyon yorucu fizikî çalışmanın yerine, yıpratıcı olmayan, zekâya dayanan nezaret etme görevini getirmektedir. Bu şimdiden bir dereceye kadar ilerlemeye işaret sayılabilir. Bu geçiş döneminde genç elemanlar - için yeni bir çraklık devresi lâzım gelecek; teknik tahsil için yaşı ileri olanların insanî ve âdil bir surette issten uzaklaştırılmaları icabedecektir. Bu yapılmadığı taktirde başgösterecek olan sosyal gerginlik otomasyonun dengesini tehlikeye koyacaktır.

Ister kati, ister elâstikî osun otomatize oluş yalnız fizikî yorgunluğu hafifletmekle kalmayıp, ayni zamanda sinir ve zihin yorgunluklarını da bir dereceye kadar hafifletecektir. Ikinci sanayi devriminin makinel zri kaslar gibi sinirleri de rahata kavuşturacaktır. Sık sık ve yerinde olarak tenkid edilen, bir tek operasyonun tekrarından doğan monotonluk yavaş, yavaş ortadan kalkacaktır. Makine - esirin zamanla, insanın insanla değil, makinenin makineyle münasebetlerini karakterize etmesi mümkündür. Charles Chaplin'in «Modern Times»'da yaptığı tahammül edilmez ağır is, çocuklarımızın inanmakta zorluk çekecekleri bir anı olacaktır.

Ne dereceye kadar genişleyeceğinin tahmini güç olan ikinci ve daha etkili bir sonuç daha olacaktır. Teknisyenler, umumiyetle yeni imalât usullerinin, eskilerinden daha iyi otomatize olduğu kanaatine varmağa mecbur kalmışlardır. Bazı vakalarda, tecrübe göstermiştir ki, muhafazakâr makinelerle mücehhez bir imalât kolunun otomatize olması yeter derecede kâr temin etmemiştir. Makinelerin yeni hale intikal edebilmesi için tekrar çizilip, inşa edilmesi icabetmektedir. Bazan yalnız imalât usulü değil, bizzat imal edilen malın şekli değiştirilmiştir. $\mathrm{Bu}$, endüstride yeni bir plânlamadır. Acaba Otomasyon ne dereceye kadar hayatımızı değiştirecektir?

Böylece otomasyonu kabul edebilmek için toplumsal yapımızın, bazı kısımlarında az, diğerlerinde daha çok düzeltme ve değişmeler yapmak gerekecektir. Vergi sistemimizde, sosyal güvenlik, iş gününün uzunluğu, imalâtta, ferdî münasebetler ve diğer bütün alanlarda değişmemiz icabedecektir. Acaba bu mümkün müdür? Insan toplumlarını incelemiş biri için bu şüphesiz mümkündür. Toplumsal toplumları katı vya elâstikî medeniyetlere sahip gerçekler olarak gruplandırmak doğru olur mu bilmiyorum. Her hal şeklinin hüküm sürdükleri yer ve zamana göre değişen fayda ve 
mahzurları olabilir. Bizim toplumumuzda otomasyonun feveran etmesi sonunda, daha elâstikî bir medeniyet seçmek zorunda mı kalınacaktır? Bu çok muhtemel görünmektedir.

İkinci Sanayi Devriminin göze batan karakteristik özelliği olan insan emeğinin otomatize olması bazılarına bereket olduğu, bazılarına Pandora'nın kutusu gibi görünmektedir. Bana kalırsa otomasyon ne bu saf heves, ne de bu âdeta ilkel korkuya lâyıtır. Fakat otomasyon insanların dikkatini, derin bir felsefenin doğması lüzumu üstüne çekmektedir. Bir gün makinelerin, insanların başarabileceklerini hayal bile etmedikleri bir işi başarması ihtimali, yine bir gün makinelerin insanların yalnız kendilerinin yapabileceklerini zannettikleri şeyleri yapma ihtimali, bizleri, insanı tek ve orijinal yapan şeyin ne olduğunu düşünmeğe davet etmektedir.

Mart 1960 sayıll «Western World» dergìsinden çevrilmiştir. 